\title{
RJEŠENJE KANALIZACIJE NASELJA
}

\section{Gordana Polančec}

Sveučilište J. J.Strossmayera u Osijeku,Građevinski fakultet Osijek, dipl.inž.građ. Marija Šperac

Sveučilište J. J.Strossmayera u Osijeku Građevinski fakultet Osijek, doc.dr.sc.

Sažetak: U idejnom rješenju kanalizacijskog sustava sanitarno-fekalnih otpadnih voda naselja Duzluk predložena su i razmatrana tri moguća varijantna rješenja i za svaku varijantu napravljena je procjena troškova izgradnje te tehnička valorizacija rješenja. Nakon provedene analize razrađenih varijantnih rješenja sanitarno-fekalne kanalizacije naselja Duzluk, kao tehnički najprihvatljivija a ekonomski najisplativija, odabrana je varijanta 1 , odnosno izgradnja razdjelne kanalizacije sanitarno-fekalnih otpadnih voda naselja Duzluk s tlačnim kanalizacijskim priključkom na kanalizacijski sustav Orahovice. Okosnicu kanalizacijske mreže naselja Duzluk čini glavni gravitacijski kolektor K.1. duljine cca $1.700 \mathrm{~m}$ koji je recipijent ostalih kolektora i sekundarne mreže naselja, ukupne duljine cca $3.500 \mathrm{~m}$. Sakupljene sanitarno-fekalne otpadne vode naselja Duzluk transportirat će se glavnom tlačnom stanicom i međumjesnim tlačnim cjevovodom duljine cca $1.350 \mathrm{~m}$ do kanalizacijske mreže Orahovice, u pravcu budućeg uređaja za pročišćavanje otpadnih voda.

Ključne riječi: idejni projekt, kanalizacija naselja, troškovi izgradnje

\section{DESIGN OF SETTLEMENT SEWAGE}

\begin{abstract}
The preliminary design of the sanitary sewer-sewage wastewater Duzluk settlements are proposed and discussed three possible alternatives for each variant was made estimates of construction costs and the technical evaluation of solutions. After analysis, developed alternative solutions sanitary sewage system Duzluk settlements, as well as technically acceptable and economically the most profitable, was selected Option 1, or the construction of the distribution of sanitary sewer-sewage wastewater settlement Duzluk of pressure sewer connection to the sewerage system Orahovica. The backbone of the sewerage network of settlements Duzluk a main gravity sewer K.1. length of approximately $1,700 \mathrm{~m}$, which is the recipient of other collectors and secondary network of settlements total length of approximately $3,500 \mathrm{~m}$. The collected sanitary sewage effluent settlement Duzluk main compression station and trunk pressure pipeline length of approximately $1,350 \mathrm{~m}$, will be transported to the sewage network Orahovice, towards the future Device for purifying waste water.
\end{abstract}

Key words: preliminary design, sewage settlement, construction costs 


\section{Uvod}

Naselje Duzluk te objekti oko rekreacijskog Orahovačkog jezera nemaju organiziran sustav odvodnje i pročišćavanja otpadnih voda. Odvodnja se vrši individualno preko septičkih jama ili direktnim ispustom u vodotoke i kanale. Postojeće stanje odvodnje i pročišćavanja otpadnih voda ne zadovoljava u sanitarnohigijenskom pogledu. Postojeći izgrađeni sustav odvodnje otpadnih voda Orahovice kombinacija je mješovitog i razdjelnog sustava s odvođenjem svih otpadnih voda u pravcu budućeg uređaja za pročišćavanje otpadnih voda, odnosno prijelazno je rješenje privremeni ispust u rijeku Vučicu [1].

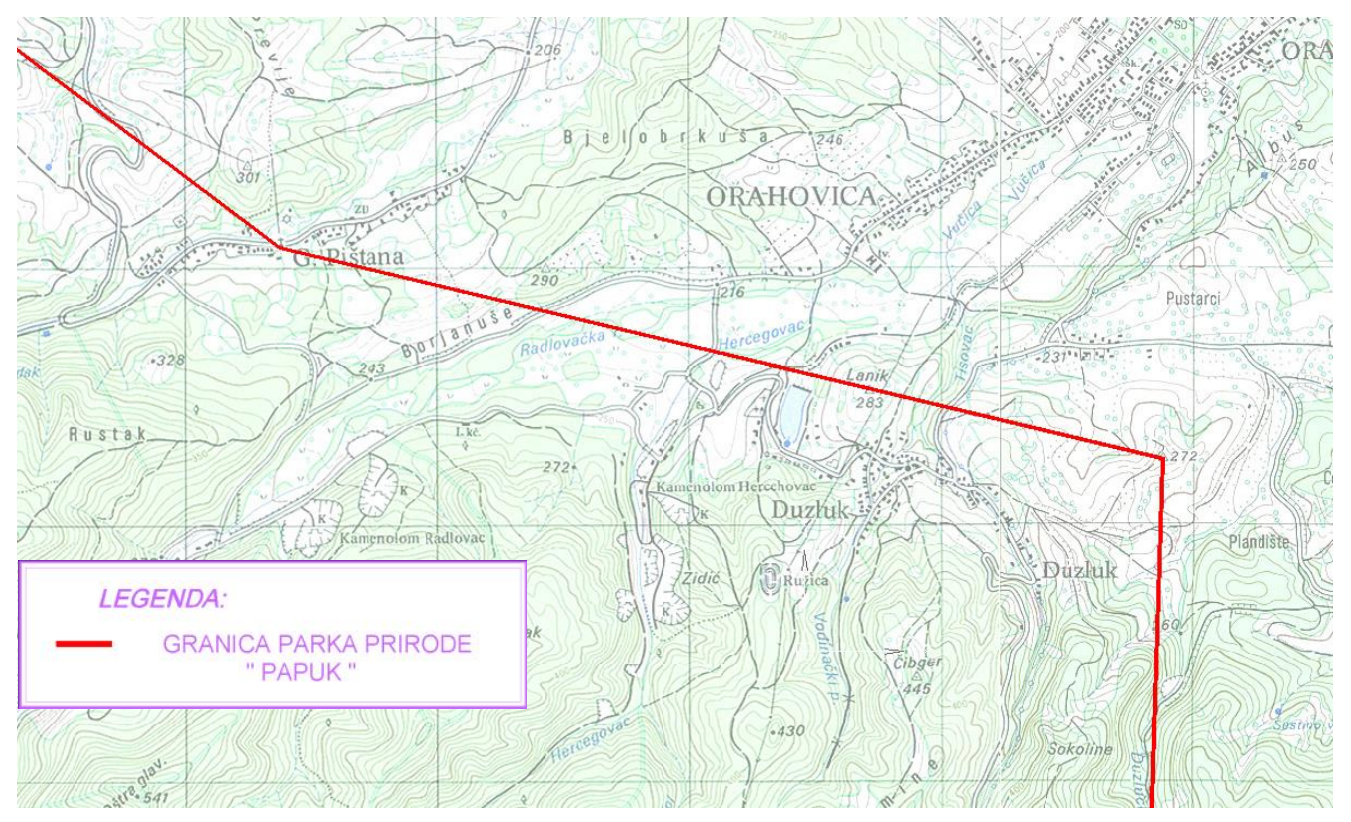

Slika 1 - Pregledna situacija granice Parka prirode Papuk [2]

Prema popisu stanovništva iz 2001. godine, grad Orahovica je ukupno imao 5.792 stanovnika. Od toga 4.262 broji sama Orahovica, a ostali su u prigradskim naseljima. U naselju Duzluk živi 201 stanovnik. Naselje je dijelom unutar granice Parka prirode Papuk (slika 1). S obzirom na izgrađene brojne kuće za odmor, u ljetnom razdoblju broj stanovnika se višestruko povećava. Na Orahovačkom jezeru značajan je i broj kupača te posjetitelja. Sve to treba uzeti u obzir pri hidrauličkom proračunu količina otpadnih voda i pri dimenzioniranju gravitacijskih kolektora, precrpnih stanica i pripadajućih tlačnih cjevovoda.

\section{Količine otpadnih voda}

Količine otpadnih voda nekog promatranog područja u izravnoj su vezi s potrošnjom vode, a definirane su sljedećim osnovnim veličinama:

1 specifična potrošnja vode po korisniku na kraju planskog razdoblja

2 broj korisnika na kraju planskog razdoblja

3 područje obuhvata i gustoća korisnika odnosno njihov raspored

4 koeficijent neravnomjernosti potrošnje.

Kako su broj korisnika na kraju planskog razdoblja, te područje obuhvata, odnosno raspored korisnika obrađeni u prethodnim točkama ovog elaborata, ostaje da se u nastavku daju prikladna objašnjenja vezana za specifičnu potrošnju vode po korisniku, odnosno koeficijentima neravnomjernosti potrošnje. Specifična norma 
otpadne vode ovisi o načinu vodoopskrbe, strukturi stanovništva, klimi i sl. Međutim, kod određivanja specifičnih normi otpadnih voda valja uzeti u obzir da se dio vode troši za kuhanje, piće, zalijevanje okućnica i drugo.

S obzirom na planirani broj stanovnika, za naselje Duzluk koristit će se vrijednost specifične potrošnje vode od $150 \mathrm{l} / \mathrm{stan} / \mathrm{dan}$. Broj ekvivalentnih stanovnika (grubo) će se procijeniti uz pretpostavku da se radi o dotoku ukupnog trajanja dnevnog otjecanja od 8 sati, te uz pretpostavku primjene specifične potrošnje vode od 150 I/stan/dan. Specifična potrošnja korisnika sadržaja rekreacijskog jezera procjenjuje se na cca $20 \mathrm{l} / \mathrm{stan} / 8$ sati.

\section{Izbor načina odvodnje}

Izbor načina odvodnje ovisi o nizu čimbenika, prvenstveno o konkretnim mjesnima prilikama i uvjetima, ekološkosanitarnim zahtjevima, tehničko-tehnološkim zahtjevima i ekonomskim pokazateljima. Prema osnovnim pokazateljima, zagađenje nastalo kućanskim otpadnim vodama znatno je opasnije od zagađenja oborinskim vodama. Količina zagađenja u godišnjem istjecanju oborinskih voda približno odgovara 10 do 12-dnevnom zagađenju kućanskim vodama (promatrano u odnosu na 1 ha gradske površine).

$S$ druge strane, industrijske otpadne vode mogu predstavljati poseban problem, naročito u slučaju ako sadrže toksične tvari koje bi štetno djelovale na izgrađene kanalizacijske objekte ili na rad zajedničkog uređaja za pročišćavanje. No, s aspekta analize pokazatelja mjerodavnih za izbor sustava odvodnje, polazi se od pretpostavke da će takve industrije svoje otpadne vode prije ispuštanja u javni kanalizacijski sustav svesti na tzv. standard normalnih kućanskih otpadnih voda.

Razdjelni sustav kanalizacije ima odgovarajućih prednosti pred mješovitim sustavom glede rada uređaja za pročišćavanje. Dotoci na uređaj su jednoličniji, i to kako sa stajališta varijacija količina, tako i u pogledu ujednačenijih karakteristika (sastava) otpadnih voda. Izostaju velike varijacije sušno/kišno razdoblje, a koje su prisutne kod mješovitog sustava i iziskuju (i pored primjene kišnih rasterećenja) odgovarajuće dopunske objekte za usklađivanje procesa pročišćavanja u kišnom periodu (dodatne taložnice, retencijske bazene i dr.).

U prednjem izlaganju navedeni su samo osnovni pokazatelji koji ulaze u sklop utjecajnih značajki za izbor najpovoljnijeg sustava kanalizacije, odnosno načina odvodnje. Općenito, izbor sustava odvodnje složene je strukture i sadržaja. No usprkos tomu, postoje i odgovarajuća usmjerenja koja su u generalnom obliku već unaprijed predodređena, poglavito na temelju postojećih lokalnih uvjeta, tj. razmještajem naselja koji bi bili obuhvaćeni odvodnim sustavom, tipa izgradnje unutar pojedinih naselja, raspoloživih prijamnika i slično.

\subsection{Osnovne postavke za izbor načina odvodnje}

Kod izbora načina odvodnje, odnosno sustava kanalizacije, među ostalim treba uzeti u obzir sve one parametre koji u osnovi utječu na svrsishodnost tehničkog rješenja, a koji su u postupku provedenih analiza već unaprijed poznati. Ovdje se prvenstveno podrazumijeva postojeća izgradnja i prostorni planovi, topografske prilike područja, hidrografske karakteristike prijamnika, položaj područja odvodnje u odnosu na prijamnik, hidrološki uvjeti u pogledu oborina i otjecanja i drugo.

U svim slučajevima izbor sustava trebao bi slijediti iz tehničko - ekonomskih analiza, uvažavajući pritom sva prisutna stanja iz složenog sadržaja sanitarnih i mjesnih uvjeta, a također i aspekte racionalnosti i mogućnosti usklađivanja rješenja za odvođenje i čišćenje sanitarno-fekalnih, industrijskih i oborinskih otpadnih voda.

Izbor sustava odvodnje treba temeljiti i na budućim uvjetima i zahtjevima, posebno uvjetima zaštite čovjekova okoliša, ali i vodeći računa o trenutačnim financijskim mogućnostima za realizaciju sustava. Pritom se sanitarni aspekt, tj. zaštita čovjekovog zdravlja nikada ne smije dovesti u pitanje.

\section{Odabrani način odvodnje}

Konkretno, za naselje Duzluk predviđena je primjena razdjelnog načina odvodnje, što podrazumijeva izgradnju sanitarno-fekalne kanalizacije naselja s priključenjem na kanalizacijski sustav Orahovice [2]. Ovakvo rješenje izgradnje, isključivo sanitarno-fekalne kanalizacije naselja Duzluk, potpuno je opravdano s obzirom da je Duzluk u kategoriji manjih naselja, a karakterizira ga pretežno rijetka stambena izgradnja na brežuljkastom području 
ispresijecanom vodotocima. Stoga se može očekivati da oborinske vode nisu jako zagađene. Odvodnja postojećih prometnica danas je već riješena jednostavnijim načinima (rigoli, jarci i sl.), dok je otjecanje $s$ preostalog dijela sliva direktno prema vodotocima.

Za izgradnju oborinske kanalizacije naselja Duzluk, osim na području oko samog rekreacijskog jezera, u ovom trenutku nema potrebe niti opravdanja pa se to može planirati tek nakon duljeg vremenskog razdoblja. Ako bi se u središtu naselja ipak pojavila potreba za djelomičnim prikupljanjem i odvođenjem oborinskih voda, rješenje se pak može pronaći u izgradnji razdjelne mreže zatvorenih oborinskih kanala i njihovim vezivanjem na otvorene vodotoke.

U idejnom rješenju kanalizacijskog sustava sanitarno-fekalnih otpadnih voda naselja Duzluk, predložena su i razmatrana tri moguća varijantna rješenja, a za svaku varijantu napravljena je procjena troškova izgradnje te tehička valorizacija rješenja.

Dvije prve i osnovne varijante u duhu su navedenog i izrađenog Koncepcijskog rješenja sustava odvodnje i pročišćavanja otpadnih voda područja "PAPUK" d.o.o. Orahovica, dok je treća varijanta zasnovana na kanalizacijskom sustavu Duzluka kao samostalnom sustavu s vlastitim uređajem za pročišćavanje otpadnih voda te ispustom u rijeku Vučicu.

\subsection{Opis varijantnih rješenja}

\subsubsection{Varijanta 1 - Tlačni priključak na kanalizacijski sustav Orahovice}

U ovoj varijanti, predviđenim razdjelnim kanalizacijskim sustavom sanitarno - fekalne otpadne vode naselja Duzluk prikupit će se zatvorenim kanalizacijskim sustavom s gravitacijskim kolektorima i precrpnim stanicama s pripadajućim tlačnim cjevovodima unutar sustava. Prikupljene otpadne vode bi se tlačno transportirale do kanalizacijskog sustava Orahovice i dalje u pravcu budućeg zajedničkog uređaja za pročišćavanje otpadnih voda, odnosno, kao prijelazno rješenje, privremenog ispusta u rijeku Vučicu (prijamnik II kategorije). Lokacija budućeg uređaja za pročišćavanje otpadnih voda je iza crpilišta Fatovi.

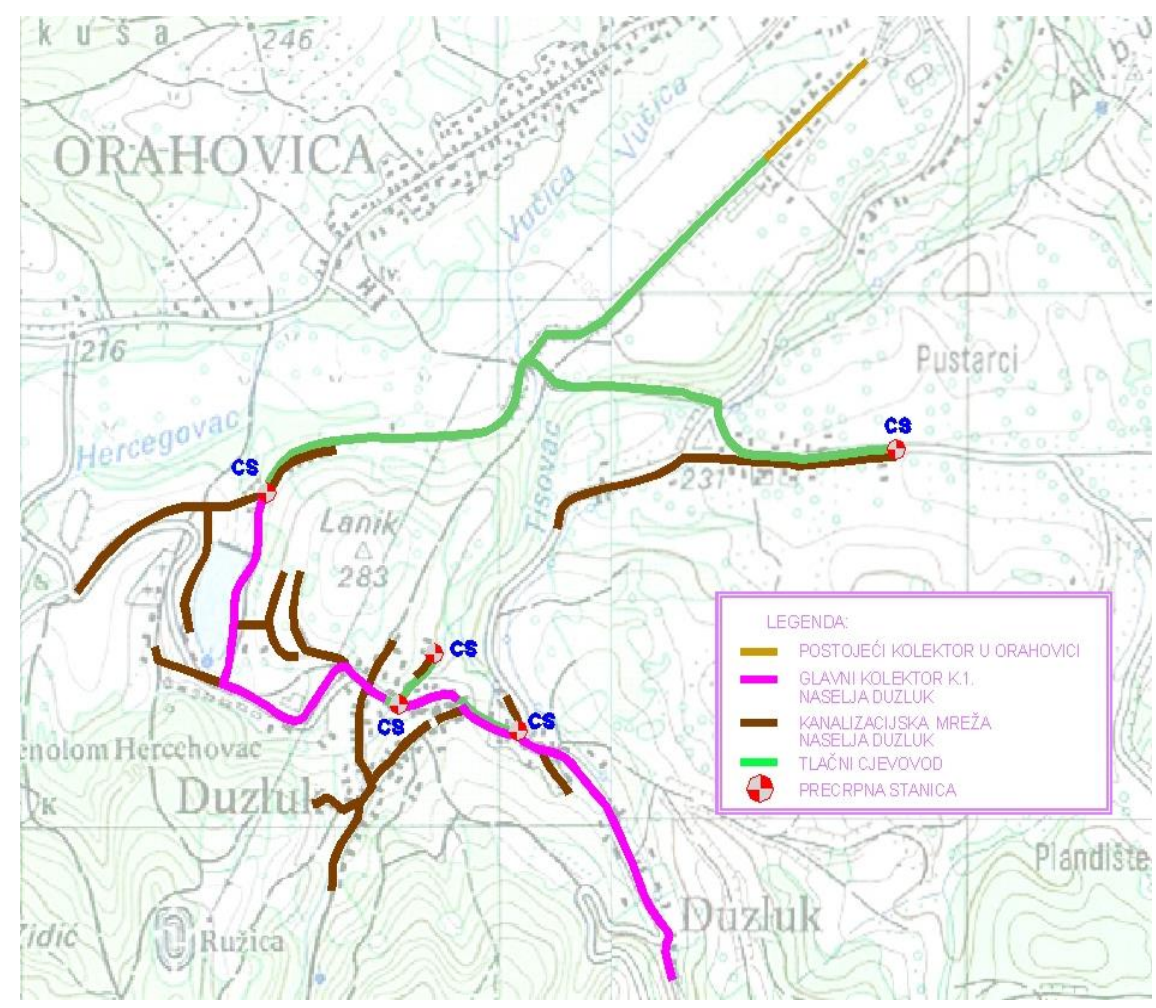

Slika 2 - Pregledna situacija - varijanta 1 [3] 
Osnovni tehnički elementi sustava su:

- glavni kolektor naselja Duzluk

$1.700 \mathrm{~m}$

- sekundarni kolektori naselja Duzluk

$3.500 \mathrm{~m}$

- precrpne kanalizacijske stanice u naselju Duzluk

4 komada

- pripadajući tlačni cjevovodi

$1.200 \mathrm{~m}$

- glavna tlačna precrpna stanica

- međumjesni tlačni cjevovod Duzluk - Orahovica

$1.350 \mathrm{~m}$.

Okosnicu kanalizacijske mreže naselja Duzluk čini glavni gravitacijski kolektor duljine cca $1.700 \mathrm{~m}$ koji je recipijent ostalih kolektora i sekundarne mreže naselja ukupne duljine cca $3.500 \mathrm{~m}$. Da bi se osiguralo tečenje otpadne vode unutar sustava gravitacijske odvodnje, tj. radi osiguranja minimalnih padova i poštivanja kriterija minimalnih dubina ukapanja kanalizacijskih cjevovoda, a uvažavajući topografiju terena, bit će izvedene četiri precrpne stanice s pripadajućim tlačnim cjevovodima za podizanje otpadne vode unutar sustava. Ukupna dužina tlačnih cjevovoda je cca $1.200 \mathrm{~m}$. Sakupljene sanitarno-fekalne otpadne vode naselja Duzluk se glavnom tlačnom stanicom i međumjesnim tlačnim cjevovodom duljine cca $1.350 \mathrm{~m}$ transportraju do kanalizacijske mreže Orahovice, u pravcu budućeg uređaja za pročišćavanje otpadnih voda.

\subsubsection{Varijanta 2 - Gravitacijski priključak na kanalizacijski sustav Orahovice}

U ovoj varijanti, predviđenim razdjelnim kanalizacijskim sustavom, sanitarno - fekalne otpadne vode naselja Duzluk prikupile bi se zatvorenim kanalizacijskim sustavom s gravitacijskim kolektorima i precrpnim stanicama s pripadajućim tlačnim cjevovodima unutar sustava. Prikupljene otpadne vode bi se gravitacijski transportirale do kanalizacijskog sustava Orahovice i dalje u pravcu budućeg zajedničkog uređaja za pročišćavanje otpadnih voda, odnosno kao prijelazno rješenje, privremenog ispusta u rijeku Vučicu (prijamnik II kategorije). Lokacija budućeg uređaja za pročišćavanje otpadnih voda je iza crpilišta Fatovi.

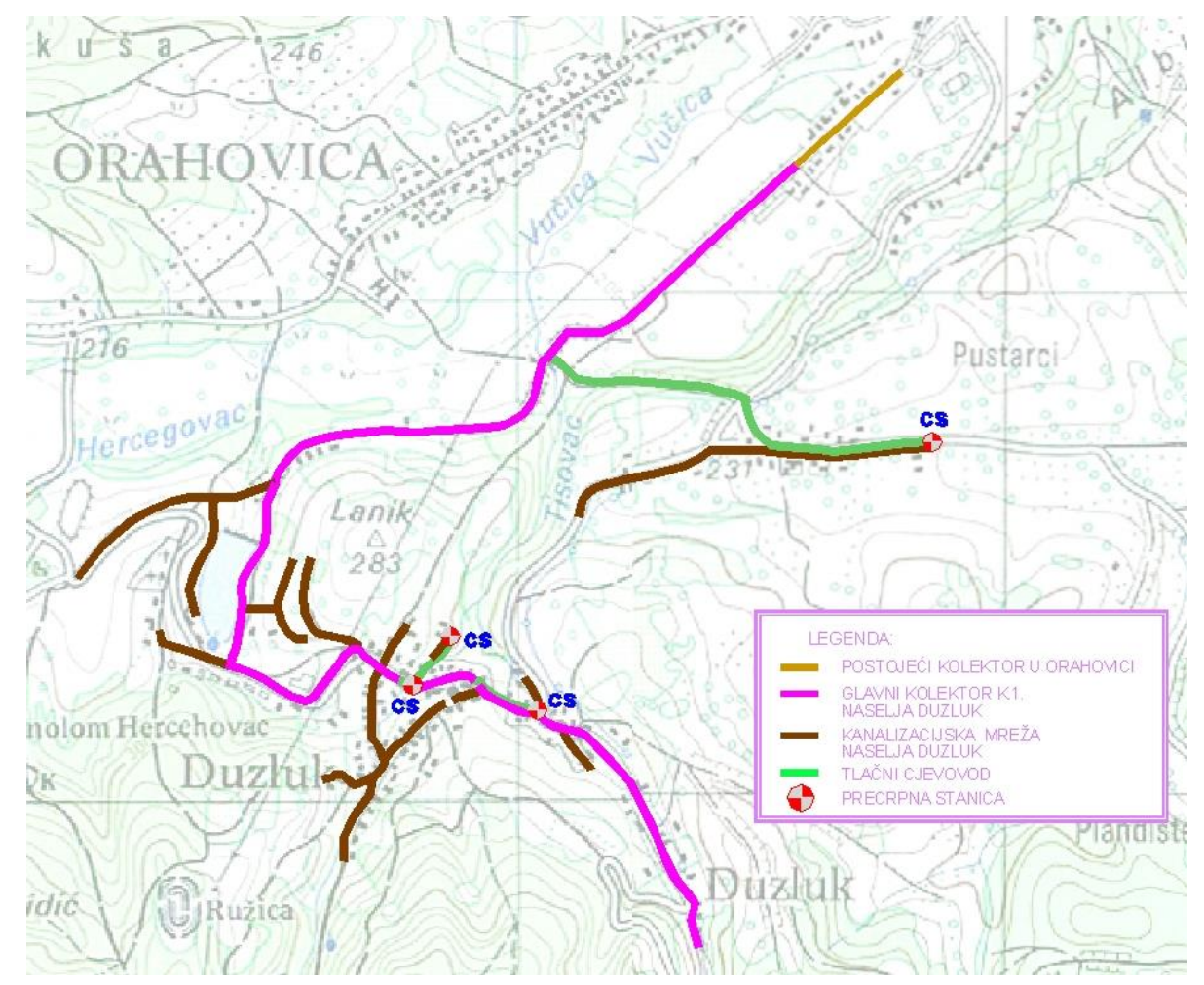

Slika 3 - Pregledna situacija - varijanta 2 [3] 
Osnovni tehnički elementi sustava su:

- glavni kolektor naselja Duzluk

$1.700 \mathrm{~m}$

- sekundarni kolektori naselja Duzluk

$3.300 \mathrm{~m}$

- precrpne kanalizacijske stanice u naselju Duzluk

4 komada

- pripadajući tlačni cjevovodi

$1.200 \mathrm{~m}$

- međumjesni gravitacijski cjevovod Duzluk - Orahovica $1.350 \mathrm{~m}$.

Okosnicu kanalizacijske mreže naselja Duzluk čini glavni gravitacijski kolektor K.1. duljine cca $1.700 \mathrm{~m}$ koji je recipijent ostalih kolektora i sekundarne mreže naselja ukupne duljine cca $3.300 \mathrm{~m}$. Da bi se osiguralo tečenje otpadne vode unutar sustava gravitacijske odvodnje, tj. radi osiguranja minimalnih padova i poštivanja kriterija minimalnih dubina ukapanja kanalizacijskih cjevovoda, a uvažavajući topografiju terena, bit će izvedene četiri precrpne stanice s pripadajućim tlačnim cjevovodima za podizanje otpadne vode unutar sustava. Ukupna dužina tlačnih cjevovoda je cca $1.200 \mathrm{~m}$. Sakupljene sanitarno-fekalne otpadne vode naselja Duzluk se međumjesnim gravitacijskim cjevovodom duljine cca $1.350 \mathrm{~m}$ transportiraju do kanalizacijske mreže Orahovice, u pravcu budućeg uređaja za pročišćavanje otpadnih voda.

\subsubsection{Varijanta 3 - Zasebni uređaj za pročišćavanje otpadnih voda}

U ovoj varijanti, predviđenim razdjelnim kanalizacijskim sustavom, sanitarno - fekalne otpadne vode naselja Duzluk prikupile bi se zatvorenim kanalizacijskim sustavom s gravitacijskim kolektorima i precrpnim stanicama s pripadajućim tlačnim cjevovodima unutar sustava. Prikupljene otpadne vode bi se transportirale do zasebnog uređaja za pročišćavanje otpadnih voda kapaciteta ES 600. Nakon pročišćavanja ispustile bi se u rijeku Vučicu (prijemnik II kategorije) [4].

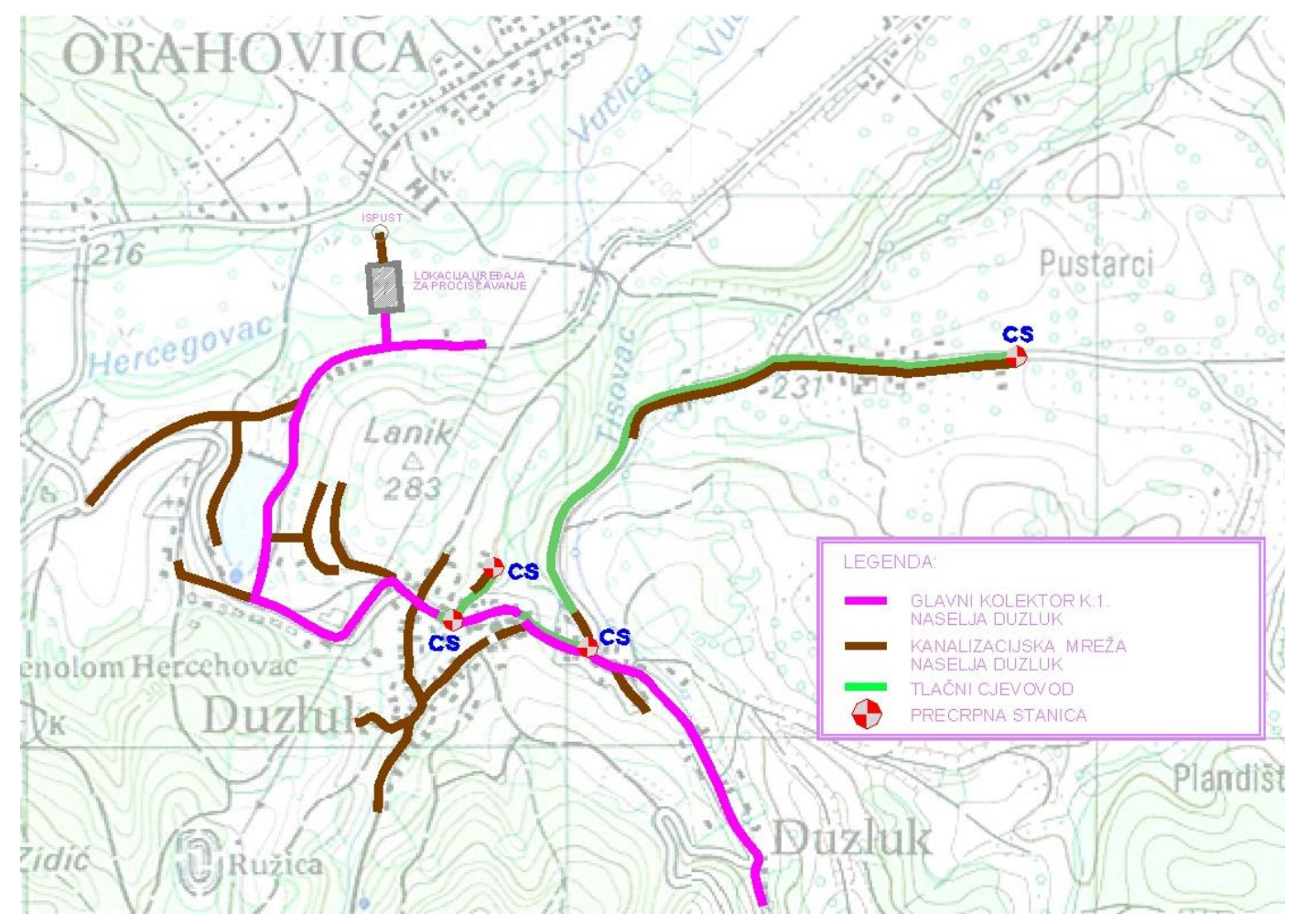

Slika 4 - Pregledna situacija - varijanta 3 [3] 
Osnovni tehnički elementi sustava su:

- glavni kolektor naselja Duzluk

$1.900 \mathrm{~m}$

- sekundarni kolektori naselja Duzluk

$3.300 \mathrm{~m}$

- precrpne kanalizacijske stanice u naselju Duzluk

4 komada

- pripadajući tlačni cjevovodi

1. $490 \mathrm{~m}$

- uređaji za pročišćavanje otpadnih voda ES 600

- tlačni cjevovod od uređaja do ispusta u Vučicu

$120 \mathrm{~m}$

Okosnicu kanalizacijske mreže naselja Duzluk čini glavni gravitacijski kolektor duljine cca $1.900 \mathrm{~m}$ koji je recipijent ostalih kolektora i sekundarne mreže naselja ukupne duljine cca $3.300 \mathrm{~m}$. Da bi se osiguralo tečenje otpadne vode unutar sustava gravitacijske odvodnje, tj. radi osiguranja minimalnih padova i poštivanja kriterija minimalnih dubina ukapanja kanalizacijskih cjevovoda, a uvažavajući topografiju terena, bit će izvedene četiri precrpne stanice s pripadajućim tlačnim cjevovodima za podizanje otpadne vode unutar sustava. Ukupna dužina tlačnih cjevovoda je cca $1.600 \mathrm{~m}$. Sakupljene sanitarno-fekalne otpadne vode naselja Duzluk dovode se do zasebnog uređaja za pročišćavanje otpadnih voda na lokaciji sjeverno od Orahovačkog jezera, te se nakon pročišćavanja ispuštaju u rijeku Vučicu.

\subsection{Tehnička valorizacija i odabir rješenja}

U idejnom rješenju kanalizacijskog sustava sanitarno-fekalnih otpadnih voda naselja Duzluk predložena su i razmatrana tri moguća varijantna rješenja te je za svaku varijantu napravljena procjena visine investicijskih ulaganja i tehnička valorizacija rješenja [5].

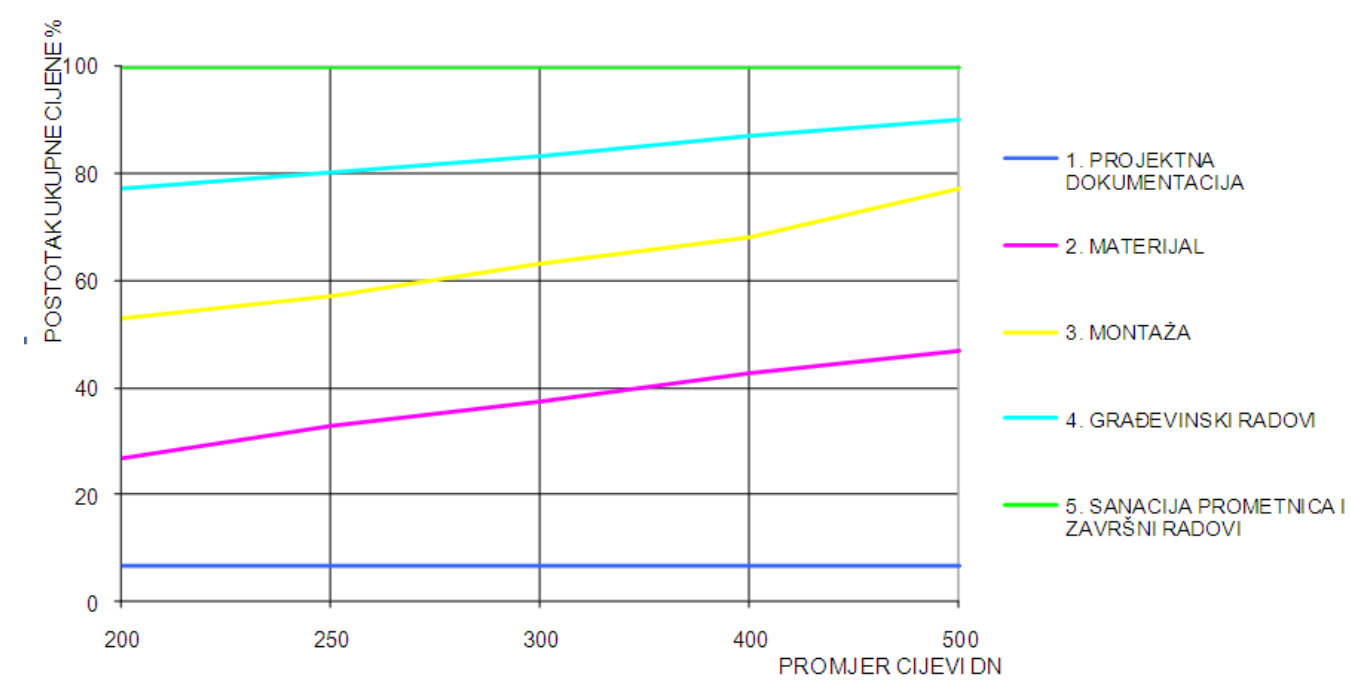

\section{Slika 5 - Struktura cijena prema radovima [3]}

Dvije prve i osnovne varijante u duhu su navedenog i izrađenog Koncepcijskog rješenja sustava odvodnje $i$ pročišćavanja otpadnih voda područja "PAPUK" d.o.o. Orahovica, dok je treća varijanta zasnovana na kanalizacijskom sustavu Duzluk kao samostalnom sustavu s vlastitim uređajem za pročišćavanje otpadnih voda te ispustom u rijeku Vučicu. Kod odabira rješenja sustava sanitarno-fekalne kanalizacije naselja Duzluk uzeti su u obzir, među ostalim, sljedeći parametri:

- svrsishodnost tehničkog rješenja u odnosu na topografske prilike područja, hidrografske karakteristike, prostorne planove te položaj područja odvodnje u odnosu na prijamnik;

- funkcionalnost tehničkih rješenja kanalizacijskog sustava;

- visina investicijskih ulaganja izgradnje varijantnih rješenja;

- održavanje kanalizacijskog sustava te pogonski troškovi;

- mogućnost faznosti izgradnje kanalizacijskog sustava. 
Nakon provedene analize razrađenih varijantnih rješenja sanitarno-fekalne kanalizacije naselja Duzluk, kao tehnički najprihvatljivija a ekonomski najisplativija, odabrana je varijanta 1 , odnosno izgradnja razdjelne kanalizacije sanitarno-fekalnih otpadnih voda naselja Duzluk s tlačnim kanalizacijskim priključkom na kanalizacijski sustav Orahovice [6].

\subsubsection{Glavni i sekundarni gravitacijski kolektori}

Glavni kolektor naselja Duzluk je recipijent ostalih kolektora i sekundarne mreže naselja Duzluk. Njime se sakupljaju sve sanitarno-fekalne otpadne vode. Ukupna dužina kolektora je cca $1.700 \mathrm{~m}$. Početak trase glavnog kolektora K.1. je kod glavne tlačne precrpne stanice (slika 6). S obzirom na uzak prostor između prometnice i građevinske linije te položene instalacije vode, plina, električne struje i telefona, trasa glavnog kolektora položit će se dijelom u bankini prometnice, a dijelom u rubu prometnice (slika 7, 8 i 9). Kraj trase glavnog kolektora je kod zadnje kuće u naselju Duzluk.

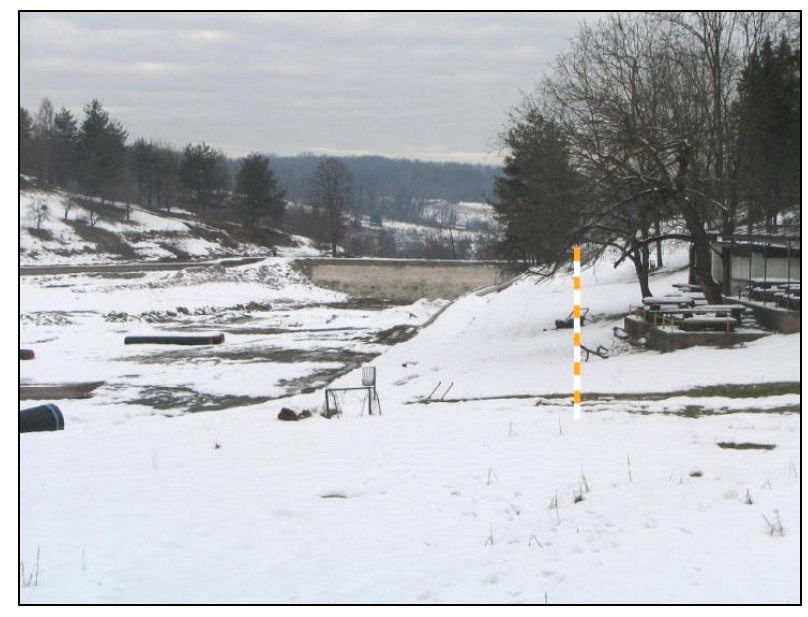

Slika 6 - Početak trase glavnog kolektora [3]

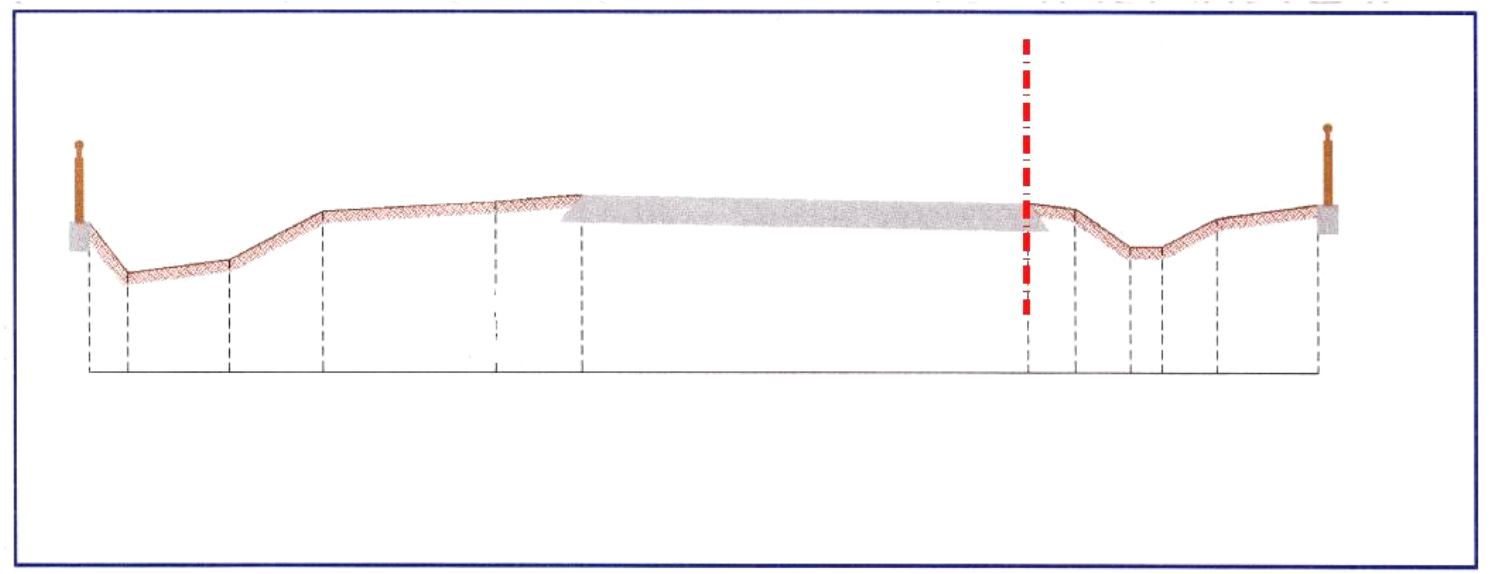

Slika 7 - Karakteristični poprečni presjek, glavni kolektor u rubu prometnice [3]

Sekundarni kolektori, s obzirom na uzak prostor između prometnice i građevinske linije te položene instalacije vode, plina, električne struje i telefona, položit će se u bankini sporednih ulica (slika 7). Ukupna duljina sekundarnih kolektora je cca $3.500 \mathrm{~m}$. 


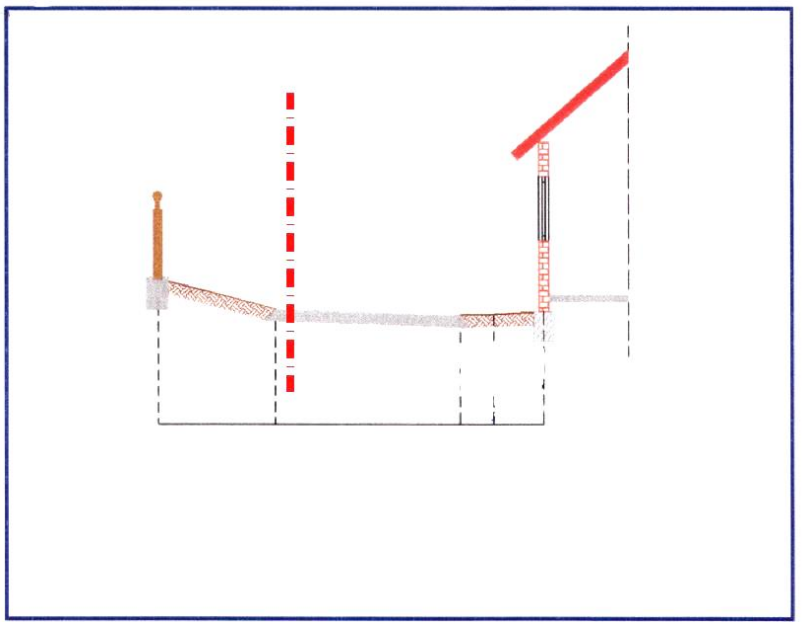

Slika 8 - Karakteristični poprečni presjek [3]

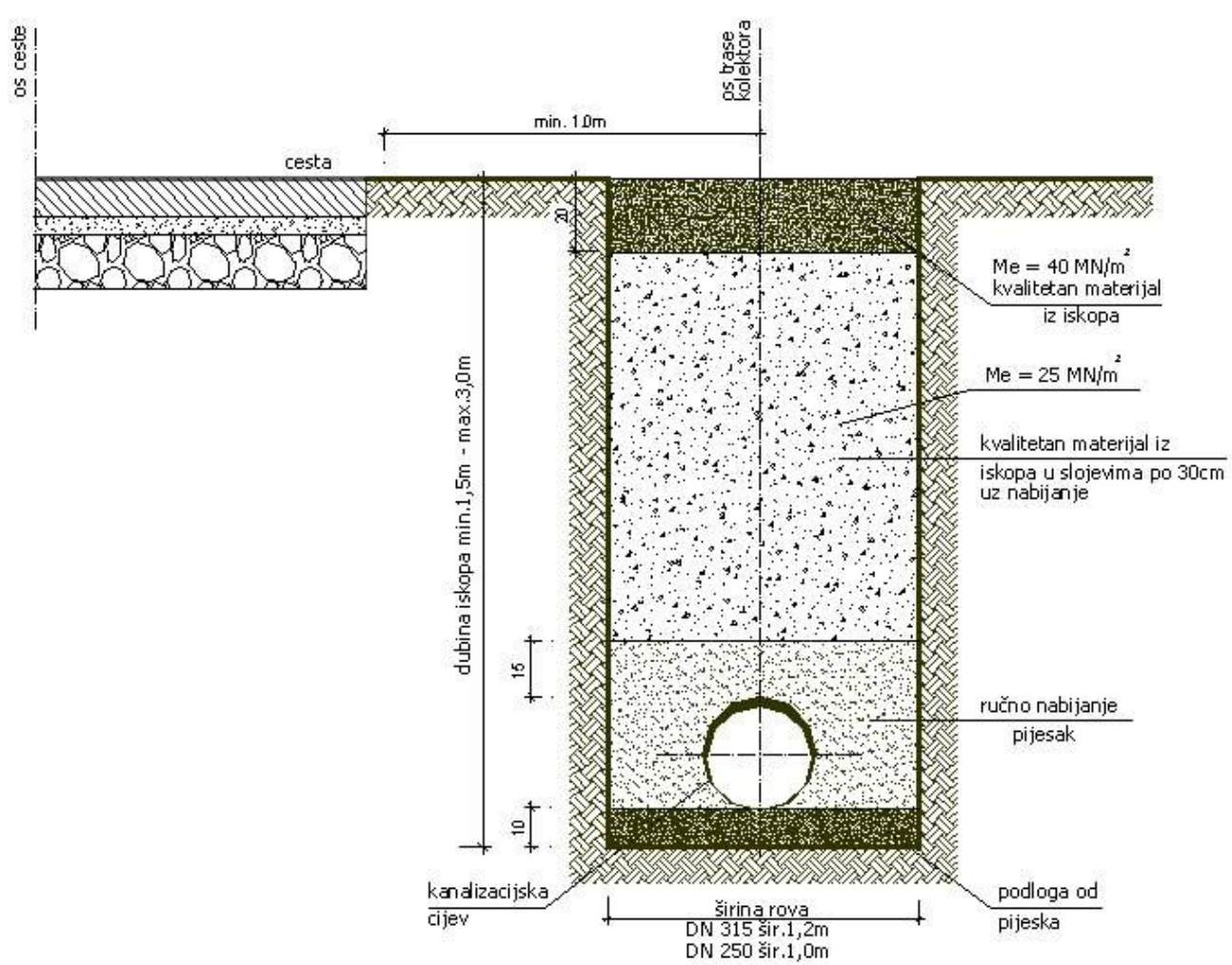

Slika 9 - Normalni poprečni profil rova kanalizacije [3]

U glavni kanalizacijski kolektor ulijevaju se sanitarno-fekalne otpadne vode iz svih kolektora i cjelokupne sekundarne kanalizacijske mreže naselja Duzluk. Potom se glavnom tlačnom stanicom i pripadajućim tlačnim cjevovodom transportiraju do spojnog okna kanalizacijskog sustava Orahovica.

Niveleta projektiranih kanalizacijskih cjevovoda položena je tako da budu zadovoljeni uvjeti minimalnih brzina tečenja u kolektorima te da količine iskopa i potrebni opseg radova kod izvođenja budu što manji, uz osiguranu mogućnost priključenja ostalih kanalizacijskih cjevovoda cjelokupnog sustava. U visinskom pogledu, niveleta uglavnom prati pad terena, a položit će se na dubinu od min. 1,5 do maksimalno $3 \mathrm{~m}$.

Gravitacijski kanalizacijski kolektori predviđeni su od vodonepropusnih PVC kanalizacijskih cijevi, a točan profil utvrdit će se hidrauličkim proračunom u glavnom projektu. 


\subsubsection{Tlačni kanalizacijski cjevovodi}

Unutar gravitacijske mreže potrebne su četiri precrpne stanice za podizanje otpadne vode radi osiguranja tečenja u cjevovodima i smanjenja dubine ukopavanja. Pripadajući tlačni cjevovodi su ukupne duljine $1.200 \mathrm{~m}$, a položit će se djelomično u isti rov s gravitacijskim kolektorom, a dijelom u zasebni rov. Trase tlačnih kanalizacijskih cjevovoda položene su u koridoru javne cestovne površine, prateći teren, dijelom u bankini prometnica, dijelom rubom prometnice, a dijelom rubom cestovnog jarka. Međumjesni tlačni cjevovod, od glavne tlačne stanice u Duzluku do uljevnog revizijskog okna u Orahovici. Duljina mu je cca $1.350 \mathrm{~m}$.

Tlačni kanalizacijski cjevovodi predviđeni su od PEHD vodovodnih cijevi, a točan profil utvrdit će se hidrauličkim proračunom u glavnom projektu. Prilikom polaganja nivelete nastojalo se da gornji rub kanalizacijske cijevi bude na dovoljnoj dubini ispod terena kako bi se osigurao dovoljan nadsloj u pogledu statičke i termičke zaštite, tj. na minimalnoj dubini od $1,3 \mathrm{~m}$.

\section{Hidraulički proračun}

Odvodnja je predviđena razdjelnim sustavom, tj. predviđa se odvodnja sanitarno-fekalnih voda zatvorenim kanalizacijskim sustavom, a oborinske vode područja odvode se postojećom otvorenom kanalskom mrežom. S obzirom na navedeno, modelirani glavni kolektor opterećen je isključivo sanitarno-fekalnim otpadnim vodama. Količina sanitarno-fekalnih otpadnih voda sustava u direktnoj je ovisnosti o potrošnji vode, odnosno broju stanovnika te normi potrošnje po stanovniku. Usvojena norma potrošnje za naselje Duzluk iznosi 150 l/stan/dan.

$$
\begin{gathered}
\mathrm{Q}_{\text {max .dan }}=\frac{\mathrm{N}_{\text {stan. }} \cdot \mathrm{Q}_{1 / \text { stan./dan }}}{86400} \cdot \mathrm{K}_{\text {max.dan }} \\
\mathrm{Q}_{\text {max .sat }}=\frac{\mathrm{N}_{\text {stan. }} \cdot \mathrm{Q}_{1 / \text { stan./dan }}}{86400} \cdot \mathrm{K}_{\text {max.dan }} \cdot \mathrm{K}_{\text {max.sat }}
\end{gathered}
$$

Prema popisu stanovništva iz 2001. godine, u naselju Duzluk živi 201 stanovnik. Prema procjeni, broj povremenih stanovnika u kućama za odmor je cca 100. Broj korisnika sadržaja oko rekreacijskog jezera procijenjen je na cca 1000 u maksimalnom danu. S obzirom na plansku dokumentaciju vezanu za uređenje rekreacijskog jezera, u planskom razdoblju broj korisnika planiranih sadržaja bi se mogao kretati od 2-4000 u maksimalnom danu.

Kako su u normu potrošnje uračunati i gubitci koji se javljaju u sustavu, ukupna potrošnja umanjena je za te gubitke, cca 20 \% potrošnje, koji u konačnici ne predstavljaju opterećenje kanalizacijskog sustava. Usvajajući pretpostavke o ukupnom broju stanovnika, normama potrošnje, koeficijentima oscilacije potrošnje te navedenim gubitcima, dobivene su ukupne vrijednosti maksimalnih dnevnih i maksimalnih satnih opterećenja. Uzimajući u obzir sanitarno-fekalne otpadne vode i procjedne vode, mjerodavno opterećenje otpadnim vodama za kanalizacijski sustav naselja Duzluk iznose:

$\begin{array}{llll}\text { Stalni stanovnici: } & Q_{\text {max.dan }}=0,56 \quad l / s \quad Q_{\text {max.sat }}=1,4 \quad l / s \\ \text { Povremeni stanovnici: } & Q_{\text {max.dan }}=0,28 \quad l / s \quad Q_{\text {max.sat }}=0,69 \mathrm{ll} / \mathrm{s} \\ \text { Korisnici sadržaja oko rekreacijskog jezera: } & Q_{\text {max.dan }}=1,85 \mathrm{ll} / \mathrm{s} \\ \text { Ukupna količina otpadne vode od stanovništva: } & Q_{u k . s \text { tan.dan }}=2,69 \quad \mathrm{ll} / \mathrm{s}\end{array}$


Kao dodatno opterećenje kanalizacijskog sustava uračunate su procjedne vode koje su, prema literaturi [7], $0,036 \mathrm{l} / \mathrm{s} / \mathrm{ha}$, a za kanalizacijski sustav naselja Duzluk iznose $0,9 \mathrm{l} / \mathrm{s}$.

Sveukupna količina otpadne vode: $\quad Q_{\text {ukupno }}=3,59 \quad l / s$

Odvodnja oborinskih voda nije predmet ove projektne dokumentacije.

\subsection{Dimenzioniranje glavnog kolektora}

S obzirom na male količine sanitarno-fekalne otpadne, profil kanalizacijskih cijevi DN $300 \mathrm{~mm}$ odabran je na osnovi tehničkih uvjeta održavanja. Duljina glavnog kolektora je $L=1700 \mathrm{~m}$. Provjera profila cjevovoda izvršena je po Prandl-Kolbrukovoj formuli za dimenzioniranje PVC okruglih kanalizacijskih cijevi s koeficijentom hrapavosti unutrašnjosti cijevi $k_{b}=0,40 \mathrm{~mm}$. Minimalni uzdužni pad predmetnog kolektora određen je uzdužnim padom prometnice i iznosi od cca $5 \%$.

$D_{0}=300 \mathrm{~mm} \quad I_{\text {min }}=5 \% \quad K_{0}=0,4 \mathrm{~mm}$

$\Rightarrow$ iz literature [7] tablice $\quad Q=81,8 \mathrm{l} / \mathrm{sec} \quad v=1,16 \mathrm{~m} / \mathrm{sec}$

Maksimalni dotok $\quad Q_{\max }=3,6 \mathrm{l} / \mathrm{sec}$

$\frac{Q_{\max }}{Q}=0,044$

iz dijagrama za $\frac{Q}{Q_{p p}}=0,044 \quad \Rightarrow \quad \frac{h}{h_{p p}}=0,12 \quad \frac{v}{v_{p p}}=0,48$

- visina punjenja kod maksimalnog dotoka:

$h_{m}^{\prime}=\frac{h}{h_{p p}} * D_{0}=0,04 \mathrm{~m} \quad v_{m}^{\prime}=\frac{v}{v_{p p}} * v=0,5 \mathrm{~m} / \mathrm{sec}$

Usvojeni profil kanalizacijskih cijevi DN 300 mm odabran je na osnovi tehničkih uvjeta održavanja.

\subsection{Dimenzioniranje glavne tlačne stanice kapaciteta $q=5 \mathrm{l} / \mathrm{s}$}

Minimalni potrebni radni volumen sabirnog okna može se izračunati iz izraza [7]:

$$
\begin{aligned}
& V=0.9 \cdot \frac{Q}{z} \\
& V=0.45 \mathrm{~m}^{3}
\end{aligned}
$$

$\mathrm{V}\left[\mathrm{m}^{3}\right] \quad$ potrebni radni volumen

$\mathrm{z}\left[\mathrm{h}^{-1}\right] \quad$ odabrani broj ciklusa rada po satu

$\mathrm{Q}[\mathrm{l} / \mathrm{s}] \quad$ kapacitet crpke.

Odabran je crpni bazen unutarnjeg presjeka $2.0 \times 1.5 \mathrm{~m}$ s korisnom visinom stupca vode $\mathrm{h}=0.3 \mathrm{~m}$, pri čemu stvarni radni volumen bazena iznosi $\mathrm{V}=0.9 \mathrm{~m}^{3}$. S obzirom na protoke, odabiru se jedna radna i jedna pričuvna crpka u naizmjenično programiranom radu. 
Kao tlačni cjevovod unutar precrpne stanice preliminarno se odabiru cijevi iz NL DN150, a podzemni cjevovod PEHD DN140 [4]. Usvaja se jedna radna i jedna pričuvna potopljena crpka s reznom pločom radnog kola, karakteristika:

$$
\begin{aligned}
& \text { - količina dobave } Q=5,0 \mathrm{l} / \mathrm{s} \\
& \text { - visina dobave } H=1,5 \text { bar } \\
& \text { - snaga } \quad P=4-6 \mathrm{~kW} \\
& \text { - napon } \quad 380 \mathrm{~V} / 50 \mathrm{~Hz} \text {. }
\end{aligned}
$$

\section{Zaključak}

Ovakvo rješenje izgradnje, isključivo sanitarno-fekalne kanalizacije naselja Duzluk, potpuno je opravdano s obzirom da je Duzluk u kategoriji manjih naselja, a karakterizira ga pretežno rijetka stambena izgradnja na brežuljkastom području ispresijecanom vodotocima. Stoga se može očekivati da oborinske vode nisu jako zagađene. Odvodnja postojećih prometnica danas je već riješena jednostavnijim načinima (rigoli, jarci i sl.), dok je otjecanje s preostalog dijela sliva direktno prema vodotocima.

Okosnicu kanalizacijske mreže naselja Duzluk čini glavni gravitacijski kolektor K.1. duljine cca $1.700 \mathrm{~m}$ koji je recipijent ostalih kolektora i sekundarne mreže naselja, ukupne duljine cca $3.500 \mathrm{~m}$. Sakupljene sanitarnofekalne otpadne vode naselja Duzluk glavnom tlačnom stanicom i međumjesnim tlačnim cjevovodom duljine cca $1.350 \mathrm{~m}$ transportirat će se do kanalizacijske mreže Orahovice, u pravcu budućeg uređaja za pročišćavanje otpadnih voda.

Kanalizacijski sustav sanitarno - fekalnih otpadnih voda naselja Duzluk zasniva se na gravitacijskoj odvodnji uz maksimalno korištenje prirodnog pada terena, te precrpnim stanicama s tlačnim cjevovodima za transport otpadnih voda u sustavu gravitacijske odvodnje. Promjeri cjevovoda će se odrediti na osnovi hidrauličkog izračuna u glavnom projektu.

$\mathrm{U}$ predmetnom idejnom rješenju razrađena je izvedba gravitacijskih kolektora i sekundarne mreže od vodonepropusnih PVC kanalizacijskih cijevi klase SN 4 SDR 41, što ne isključuje mogućnost ugradnje PEHD ili nekih drugih kanalizacijskih cijevi, o čemu investitor donosi odluku tijekom izrade glavnih i izvedbenih projekata kanalizacije [4].

\section{Literatura}

[1] Koncepcijsko rješenje sustava odvodnje otpadnih voda područja Papuk d.o.o. Orahovica - Sustav odvodnje Orahovica, Hidroing d.o.o. Osijek, 2002.

[2] Prostorni plan uređenja Općine Orahovica, Zavod za prostorno uređenje Virovitičko - podravske županije, (Službeni glasnik 4/07)

[3] Polančec, G. (2011): Rješenje kanalizacije naselja, diplomski rad

[4] Studija odvodnje i pročišćavanja otpadnih voda na slivu Karašice - Vučice, Hidroprojekt-ing d.o.o. Zagreb i Hidroing d.o.o. Osijek, 2002.

[5] HDPE kanalizacijski sustavi, Tehnički priručnik

[6] Standardna kalkulacija radova u vodogradnji (Hrvatske vode, Zagreb 2009.)

[7] Margeta, J. (1998): Kanalizacija naselja, Sveučilište u Splitu, Građevinski fakultet Split 